\title{
КОМПЛЕКСНА ОЦІНКА МЕДИКО-СОЦІАЛЬНИХ ДЕТЕРМІНАНТ ЗДОРОВОГО СПОСОБУ ЖИТТЯ У ВІЙСЬКОВОСЛУЖБОВЦІВ ВІЙСЬКОВО-МОРСЬКИХ СИЛ ЗБРОЙНИХ СИЛ УКРАЇНИ
}

\author{
І.К. Середа 1 , Ж.М. Олещенко² \\ 1 Українська військово медична академія, м. Київ, Україна \\ ${ }^{2}$ Командування Морської піхоти Військово-Морських Сил ЗС України, м. Миколаїв, Україна
}

\begin{abstract}
Мета роботи: комплексно оцінити медико-соціальні детермінанти здорового способу життя у військовослужбовців ВМС ЗС України для виявлення найвагоміших ризиків і розробці на цій основі сфокусованих заходів щодо їх зменшення.

Матеріали та методи. Медико-соціальні аспекти виконання вимог здорового способу життя у військовослужбовців ВМС ЗС України були проаналізовані за результатами соціологічного опитування 3 застосуванням спеціально розробленої анкети. Анкета включала 43 питання, що були зведені в інформаційні блоки. Методом випадкової вибірки було проведено анкетне опитування 128 військовослужбовців ВМС ЗС України, які проходили поглиблене медичне обстеження в 2019 році. В

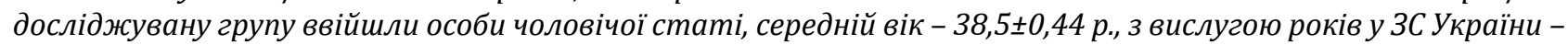

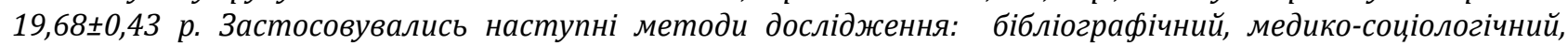
медико-статистичний, системний аналіз.

Результати. У статті розглянуто медико-соціальні аспекти виконання вимог здорового способу життя у військовослужбовців ВМС ЗС України за результатами соціологічного опитування 3 застосуванням спеціально розробленої анкети. Анкета включала інформаційні блоки: загальні відомості, поінформованість щодо здорового способу життя, поширеність та причини шкідливих звичок, аналіз способу життя (особливостей харчування, фізичної активності, режиму праці та відпочинку), самооцінка стану здоров'я та таблищю щодо визначення задоволеності різними сторонами життя за наступними критеріями: умови праці та перспективи службового росту, забезпеченість житлом та побутові умови, сімейне та матеріальне благополуччя, дозвілля та медичне обслуговування, соціальний та правовий захист тощо.
\end{abstract}

Висновки. Встановлено, що для військовослужбовців ВМС ЗС України типовими чинниками, що знижують рівень здорового способужиття, є порушення режиму харчування, режиму праці та відпочинку, високий рівень шкідливих звичок та недостатній рівень фізичної активності. Незважаючи на досить високу обізнаність військовослужбовців ВМС ЗС Украӥни щодо вимог здорового способу життя, виконання даних рекомендацій залишається низьким, що піднімає проблему формування здорового способу життя у ЗС України до найбільш актуальних. Виявлено невідповідність між високим рівнем поінформованості військовослужбовців ВМС ЗС Украӥни щодо здорового способу життя і практичним виконанням цих заходів (98,1 1,1\% респондентів вважають, що мають достатньо знань про здоровий спосіб життя, але

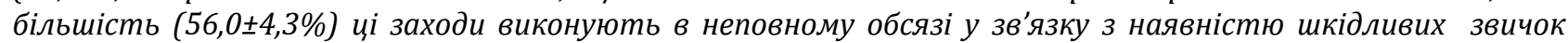

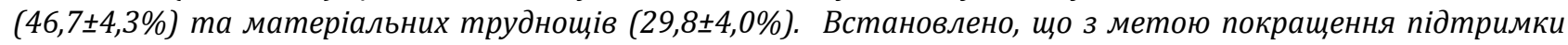
здорового способу життя за даними соціологічного опитування впровадження матеріального заохочення

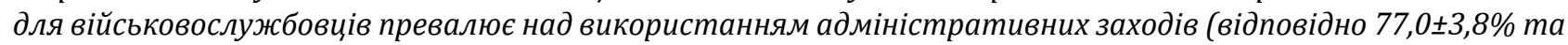

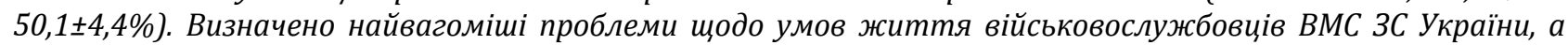
саме: незабезпеченість житлом, низький рівень матеріального благополуччя та недостатній рівень соціального і правового захисту.

Ключові слова: військовослужбовці Військово-Морських Сил ЗС Украӥни, здоровий спосіб життя, фактори ризику.

Вступ. Збереження здоров'я та повноцінного життя громадян $\epsilon$ однією 3 найважливіших цілей світової спільноти, що відображено у засадах європейської політики «Здоров'я-2020: основи Європейської політики в підтримку дій держави i суспільства в інтересах здоров'я і благополуччя» [1]. Протягом останніх років у нашій країні спостерігається низький рівень усвідомлення цінності здоров'я як власного капіталу, стрімке зниженням рівня здоров'я населення, що зумовлене соціальноекономічною кризою, погіршенням екологічної ситуації, різким падінням рівня життя, недоліками в системі охорони здоров'я тощо. Все це призводить до створення в країні несприятливих умов для ведення здорового способу життя [2].

Наразі в Україні тенденція погіршення здоров'я населення набула загрозливого рівня 
[2]. Особливу занепокоєність викликає стан здоров'я військовослужбовців Збройних Сил (далі - 3С) України.

Збереження та зміцнення здоров'я військовослужбовців, поліпшення ефективності медичної допомоги не можливі без вивчення основних факторів, тенденцій та закономірностей, що впливають на їх стан здоров'я [3]. Здоров'я військовослужбовців знаходиться у тісному зв'язку з соціальноекономічними умовами, факторами служби та побуту, станом військової охорони здоров'я, його профілактичною спрямованістю, способом життя [4].

На сьогодні доведено, що з усіх факторів, детермінуючих здоров'я людини, $50-55 \%$ припадає на спосіб життя людини, а до факторів, що визначають спосіб життя відносяться раціональний режим праці й відпочинку, раціональне якісне харчування, достатня фізична активність, звички тощо [2, $5,6,7]$.

За результатами аналізу стану здоров'я за останні 5 років встановлено, що найбільший рівень загальної захворюваності характерний для Військово-Морських Сил (далі - ВМС) 3С України, що іноді майже в двічі більше узагальнених даних за всі 3С України. Враховуючи таку негативну тенденцію захворюваності серед військовослужбовців ВMC 3С України постає гостра необхідність комплексного вивчення аспектів виконання вимог здорового способу життя та пошуку нових превентивних (профілактичних) заходів.

Реформування системи охорони здоров'я України на засадах профілактичної парадигми вимагає впровадження концепції профілактичної (санологічної) спрямованості діяльності не тільки цивільної а й військової системи охорони здоров'я $[2,6,8]$.

Система попередження захворювань i усунення ризику розвитку захворювань $\epsilon$ найважливішим завданням первинної профілактики та запорукою здоров'я. Тому, дослідження медико-соціальних детермінант здорового способу життя військовослужбовців $\epsilon$ особливо актуальним завданням та обумовило дане дослідження.

Мета дослідження: комплексно оцінити медико-соціальні детермінанти здорового способу життя у військовослужбовців ВМС 3С України для виявлення найвагоміших ризиків і розробці на цій основі сфокусованих заходів щодо їх зменшення.
Матеріали та методи дослідження. Медико-соціальні аспекти виконання вимог здорового способу життя у військовослужбовців ВМС 3С України були проаналізовані за результатами соціологічного опитування з застосуванням спеціально розробленої анкети. Анкета включала 43 питання, що були зведені в інформаційні блоки: загальні відомості, поінформованість щодо здорового способу життя, поширеність та причини шкідливих звичок, аналіз способу життя (особливостей харчування, фізичної активності, режиму праці та відпочинку), самооцінка стану здоров'я.

Також анкета містила таблицю щодо визначення, за п'ятибальною шкалою, задоволеності різними сторонами життя за наступними критеріями: умови праці та перспективи службового росту, забезпеченість житлом та побутові умови, сімейне та матеріальне благополуччя, дозвілля та медичне обслуговування, соціальний та правовий захист тощо.

Методом випадкової вибірки було проведено анкетне опитування 128 військовослужбовців ВМС 3С України, які проходили поглиблене медичне обстеження в 2019 році. В досліджувану групу ввійшли особи чоловічої статі, середній вік - 38,5 $\pm 0,44$

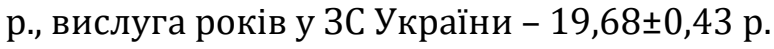

При проведенні опитування респонденту докладно пояснювався зміст процедури та наголошувалось на важливість виважених та чесних відповідей. Опитування проводилися анонімно. Питання сформульовані максимально конкретно та точно, не допускаючи неясності й неоднозначності запитань анкети. Застосовувались наступні методи дослідження: бібліографічний, медикосоціологічний, медико-статистичний, системний аналіз.

Результати та їх обговорення. Виконання основного стратегічного завдання діяльності військової системи охорони здоров'я - збереження та зміцнення здоров'я військовослужбовців, поліпшення ефективності медичної допомоги не можливі без вивчення основних факторів, тенденцій та закономірностей, що впливають на стан здоров'я військовослужбовців.

\section{Здоров’я військовослужбовців} знаходиться у тісному зв'язку з соціальноекономічними умовами, факторами служби та 
побуту, станом військової охорони здоров'я, його профілактичною спрямованістю, способом життя $[4,6,8]$.

Для більшості захворювань, особливе значення надається факторам ризику, оскільки вони відіграють значну роль у знижені резистентності макроорганізму, $\epsilon$ провокуючими чинниками розвитку та прогресування захворювань [9].

Важливо зауважити, що за результатами проведеного дослідження виявлено досить високу обізнаність військовослужбовців щодо здорового способу життя. На запитання „Чи маєте Ви достатньо знань про здоровий спосіб життя?" позитивні відповіді було отримано від $98,1 \pm 1,1 \%$ респондентів.

Щодо джерел інформації про здоровий спосіб життя, то 26,6 $\pm 3,8 \%$ військовослужбовців вказали, що поповнюють свої знання з телевізійних передач, $26,6 \pm 3,8 \%$

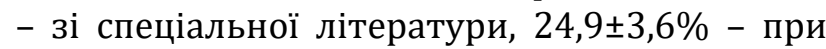
спілкуванні з лікарем, 16,4 $\pm 3,2 \%$ - зі статей в періодичній пресі та $5,5 \pm 2,2 \%$ - при спілкуванні зі знайомими.

За даними соціологічного дослідження проведеного В.Ф. Москаленко і співавт. [10] серед пацієнтів первинної ланки щодо джерел поповнення знань з аспектів профілактики, $76 \%$ опитаних звернуться за порадою до сімейного лікаря, 40\% отримають необхідну інформацію з літератури, 28\% звернуться за порадою до друзів та знайомих, 18\% - до сімейної медичної сестри, 13\% - до вузького спеціаліста, 9\% - до інтернету.

Отримані результати дослідження показали, що абсолютна більшість військовослужбовців зважено оцінює особисту відповідальність та роль в збереженні та зміцненні здоров'я. На питання, «Як ви вважаєте: хто несе основну відповідальність за стан Вашого здоров'я?» 86,8 2 ,9\% опитаних військовослужбовців відповіли - «я особисто»,

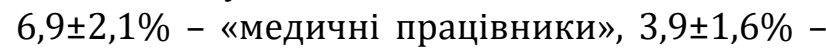

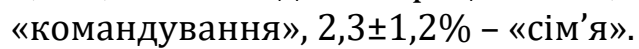

Ми провели оцінку обізнаності військовослужбовців щодо загальновизнаних основних чинників, які впливають на стан здоров'я. Більшість опитаних, а саме 47,0 4 ,3\% військовослужбовців, на 1-ше місце ставлять спосіб життя, 29,6 $23,9 \%$ - спадкові фактори, $13,1 \pm 2,8 \%$ - стан екології та 10,3 $\pm 2,6 \%$ медичне обслуговування.

Згідно загальноприйнятої класифікації американського вченого Роббінса, стан здоров'я населення на 51-52\% залежить від способу життя, на 19-20\% від біологічних чинників, на $17-20 \%$ - факторів навколишнього середовища та лише на 8-10\% від суто медичних факторів $[5,10]$. Отриманий нами розподіл відповідей серед здорових військовослужбовців в більшій мірі співпадає із вищенаведеними даними.

Проведений нами аналіз результатів соціологічного опитування показав невідповідність між рівнем поінформованості військовослужбовців щодо здорового способу життя і практичним виконанням. Загалом, військовослужбовці, оцінюючи в балах виконання рекомендацій щодо здорового способу життя і профілактики захворювань, в більшості $(56,0 \pm 4,3 \%)$ оцінили себе на три бали за 5-ти бальною шкалою (рис. 1).

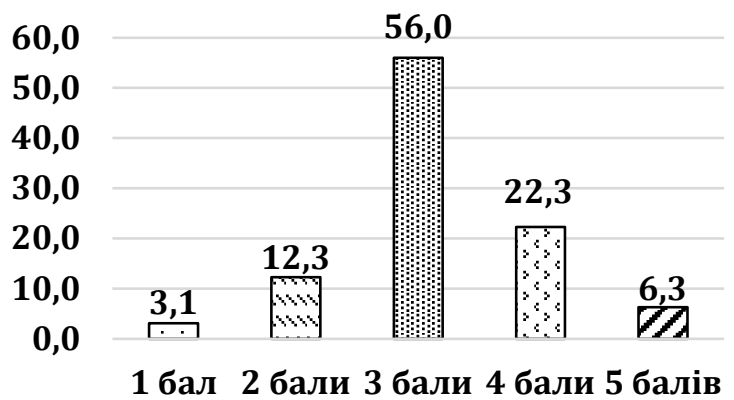

Рисунок 1. Результати самооцінки військовослужбовцями $(\mathrm{n}=128)$ виконання рекомендацій щодо здорового способу життя i профілактики захворювань за 5-ти бальною шкалою, \%.

Серед причин, які перешкоджають впровадженню здорового способу життя опитані нами військовослужбовці найчастіше визначили - звички $(46,7 \pm 4,3 \%)$ та матеріальні труднощі $(29,8 \pm 4,0 \%)$. Лише $12,7 \pm 2,6 \%$ військовослужбовців вказують на відсутність мотивацій, та $10,8 \pm 2,6 \%$ - на відсутність знань. Але, разом з цим, 77,0 $3,8 \%$ військовослужбовців відповіли, що вважають доцільним впровадження матеріального заохочення для військовослужбовців, які не мають хибних звичок і підтримують високий

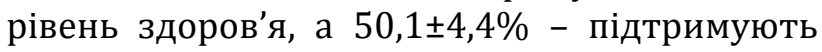
використання адміністративних заходів для спонукання ведення військовослужбовцями здорового способу життя. $86,7 \pm 2,7 \%$ опитаних військовослужбовців впевнені, що у ВМС ЗС України необхідне підвищення рівня пропаганди здорового способу життя.

Наступним блоком запитань був аналіз поширеності серед військовослужбовців шкідливих звичок - куріння та прийому алкогольних напоїв, оскільки куріння найвагоміший фактор ризику серцево- 
судинних захворювань і інших неінфекційних захворювань $[10,11,12,13,14]$.

Виявлено, що $30,7 \pm 4,1 \%$ респондентів

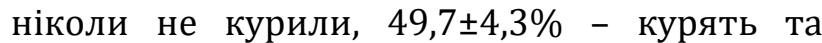
курили в минулому - 19,6 $\pm 3,5 \%$. Ці дані збігаються з даними, що виявлені в загальній популяції міських мешканців України $[5,10]$ та військовослужбовців $[4,6,8,14]$.

Також, як і за даними популяційних досліджень [4, 6, 8, 14], середня кількість випалюваних щодня цигарок чоловіками $\epsilon$ досить високою - 14,2 \pm ,7: до 10 цигарок викурюють 38,2\%, 20 і більше - 35,3\% та від 11 до $19-26,5 \%$.

Серед респондентів, які курять, $92,6 \pm 2,2 \%$ вважають, що куріння шкодить їхньому здоров'ю та $73,5 \pm 3,9 \%$ бажають кинути курити, при цьому $61,8 \pm 4,3 \%$ раніше мали спроби позбавитись цієї шкідливої звички.

Ми провели аналіз чинників, які спонукають військовослужбовців до куріння: $52,8 \pm 4,3 \%$ курять, щоб зняти психоемоційне напруження, $5,8 \pm 1,9 \%$ - скоротати час, $2,9 \pm 1,4 \%$ - за компанію, залежність від тютюну визнали 26,5 $\pm 3,8 \%$ військовослужбовців, $12,0 \pm 2,7 \%$ не могли визначити причину куріння.

Алкогольні напої вживають 89,4 $\pm 2,7 \%$ військовослужбовців, при цьому більшість $(60,9 \pm 4,2 \%)$ респондентів вживають алкогольні напої у вихідні та святкові дні, $24,1 \pm 3,8 \%$ - 1 раз на місяць, 2-3 рази на

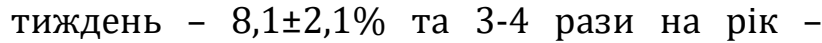
$6,9 \pm 2,1 \%$.

Наступним блоком питань ми проводили детальний аналіз способу життя: особливостей харчування, фізичної активності, режиму праці та відпочинку.

Одним 3 найбільш важливих компонентів здорового способу життя являється раціональне та повноцінне харчування. Проте дослідження показало, що лише 40,8 $44,3 \%$ респондентів зазначили, що дотримуються режиму харчування, $25,8 \pm 3,8 \%$ вважають своє харчування збалансованим та раціональним. Слід відмітити, що в нашому дослідженні три-, чотириразового харчування дотримується лише $19,7 \pm 3,5 \%$ респондентів, $2-3$ рази на день харчується $57,3 \pm 4,3 \%$ військовослужбовців та 1-2 рази на день $23,0 \pm 3,6 \%$. При цьому основний прийом їжі у $73,9 \pm 3,9 \%$ респондентів припадає на вечірні години.

Виявлено, що лише $8,7 \pm 2,4 \%$ військовослужбовців дотримується дієтичного $\quad$ харчування; $\quad 21,7 \pm 3,6 \%$ респондентів надають перевагу гострим, соленим та консервованим продуктам; $56,4 \pm 4,3 \%$ - жирним, жареним, копченим продуктам; $13,2 \pm 2,8 \%$ - виробам 3 тіста, кондитерським виробам та солодощам.

Недостатнє вживання овочів та фруктів $\epsilon$ вагомим фактором ризику розвитку серцевосудинних захворювань. Аналіз даних добового споживання військовослужбовцями овочів та фруктів дозволив встановити, що щоденно більше 400 г овочів та фруктів вживають лише $7,9 \pm 2,3 \%$ респондентів, $32,3 \pm 4,1 \%-200-400$ г, $49,8 \pm 4,4 \%$ - 100-200 г та $10,0 \pm 2,6 \%$ - менше 100 г.

Необхідно відзначити, що виявлений нами нераціональний режим харчування (нерегулярне харчування, основний прийом їжі у вечірні години) та нераціональний склад добового раціону (надмірне вживання жирної, жареної їжі, гострих, солених продуктів, та недостатнє вживання овочів та фруктів) відповідають харчовим уподобанням більшості населення України $[2,4,5,8,10,15$, 16].

Результати опитування свідчать, серед респондентів третина має ХСК, а саме АГ, показник іï складає $34,2 \pm 4,2 \% \quad(\mathrm{n}=44)$. При цьому $33,7 \pm 4,1 \% \quad(\mathrm{n}=43)$ мають хронічну терапевтичну патологію без супутньої АГ, решта $32,1 \pm 3,9 \% \quad(\mathrm{n}=41) \quad$ вважають себе здоровими (рис. 2).

Серед факторів ризику, одне з провідних місць займає надмірна маса тіла та ожиріння. Середні показники маси тіла в досліджуваній групі становили $26,96 \pm 0,26$. Так, надлишкова маса тіла (індекс маси тіла > 25 кг/м²) у військовослужбовців виявлена у $46,1 \pm 4,4 \%$ (n=59), ожиріння 1-ої стадії у $16,1 \pm 3,0 \%(n=20)$

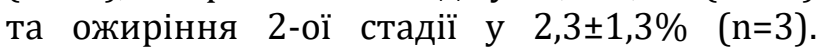
Більшість респондентів знають свою вагу $(97,6 \pm 1,3 \%)$.

При вивченні фізичної активності $69,8 \pm 4,0 \%$ військовослужбовців зазначили, що займаються фізичними вправами. При цьому

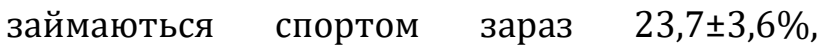
займались раніше $-49,4 \pm 4,4 \%$ та $7,5 \pm 2,2 \%$ не займались взагалі. Такі ж дані мають місце і у літературних джерелах щодо малорухомого способу життя $[2,10]$.

Середня тривалість робочого дня у

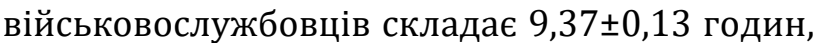
середня тривалість робочого тижня $50,7 \pm 0,97$ годин. При цьому $16,1 \pm 3,2 \%$ респондентів відповіли, що тривалість робочого дня та тижня ненормовані. 


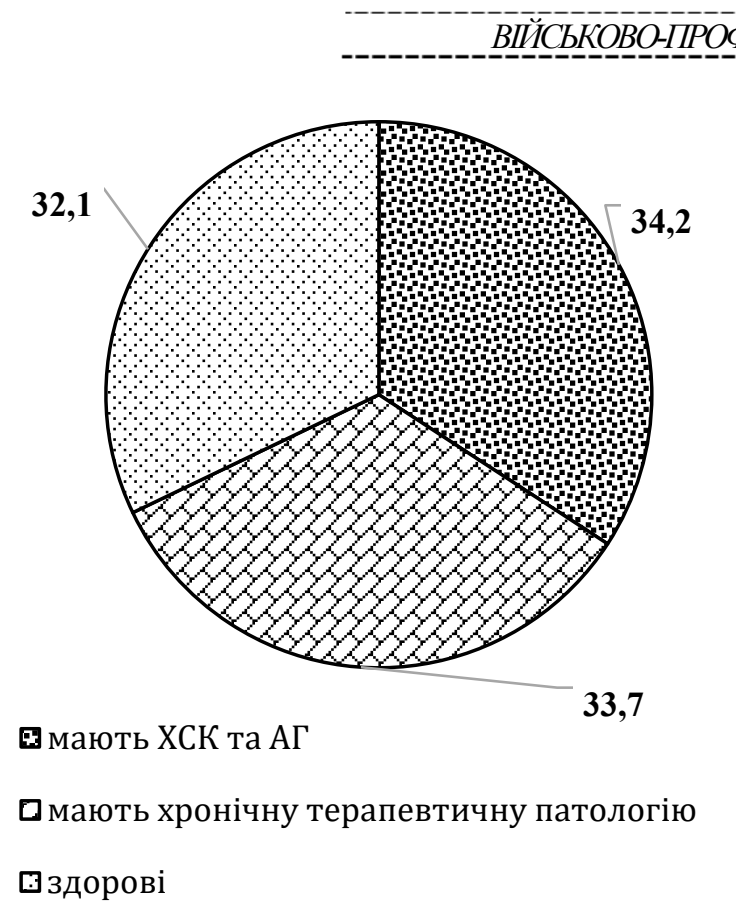

Рисунок 2. Розподіл військовослужбовців ВМС 3С України $(\mathrm{n}=128)$ про обізнаність щодо власних хвороб, \%.

Високий та помірний рівень психоемоційного навантаження на робочому місті відмітили відповідно $52,8 \pm 4,3 \%$ та $41,0 \pm 4,3 \%$ і тільки $6,2 \pm 2,0 \%$ незначний рівень. Це свідчить про те, що військова служба $\epsilon$ особливим видом людської діяльності для якої характерним $\epsilon$ комбінація високих психічних навантажень, наслідком яких $\epsilon$ психоемоційний стрес, розвиток тривожності та депресії, що призводить до виникнення психосоматичної патології $[8,17]$.

При цьому, $50,3 \pm 4,3 \%$ респондентів схильні до довготривалих переживань негативних емоцій.

Важливим чинником зміцнення здоров'я і попередження захворювань $\epsilon$ можливість повноцінного відпочинку. Дослідження показало, що не дотримуються режиму праці та відпочинку $39,4 \pm 4,3 \%$. Так, при оцінці характеру сну, як одного з показників стану нервової діяльності і психологічного комфорту, встановлено: середню тривалість сну до 6 годин відмічає $24,2 \pm 3,7 \%, 6-7$ годин $60,1 \pm 4,3 \%$ та нормальний сон тривалістю 7-8 годин відмічає лише $15,7 \pm 3,1 \%$ респондентів. Регулярно відпочивають у вихідні дні та під час відпустки $41,6 \pm 4,3 \%$ респондентів.

Суб'єктивно стан власного здоров'я військовослужбовці оцінюють у більшості як задовільний $\quad(50,4 \pm 4,3 \%)$ та добрий $(40,8 \pm 4,3 \%)$ і незначна кількість респондентів оцінюють, як незадовільно $(5,7 \pm 1,3 \%)$ та

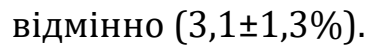

Проведено оцінку задоволеності військовослужбовцями різними сторонами свого життя, від яких може залежати самопочуття людей, за 5-ти бальною системою (табл. 1).

Таблиця 1

\section{Розподіл військовослужбовців ВМС ЗС України щодо задоволеності різними}

сторонами життя за 5-ти бальною шкалою $(\mathrm{n}=128)$

\begin{tabular}{|r|l|c|c|c|c|c|}
\hline № & \multicolumn{2}{|c|}{ Сторони життя } & \multicolumn{4}{|c|}{ Оцінка в балах, \% } \\
\cline { 3 - 6 } з/п & \multicolumn{1}{|c|}{1} & 2 & 3 & 4 & 5 \\
\hline 1. & $\begin{array}{l}\text { Робота (характер праці, умови, } \\
\text { можливості та ін.) }\end{array}$ & $3,9 \pm 1,7$ & $14,8 \pm 3,1$ & $35,8 \pm 4,2$ & $35,2 \pm 4,2$ & $10,3 \pm 2,6$ \\
\hline 2. & $\begin{array}{l}\text { Перспективи } \\
\text { зростання }\end{array}$ & $14,8 \pm 3,1$ & $20,2 \pm 3,5$ & $28,7 \pm 3,9$ & $26,8 \pm 3,8$ & $9,5 \pm 2,5$ \\
\hline 3. & Забезпеченість житлом & $19,9 \pm 3,4$ & $15,6 \pm 3,1$ & $31,3 \pm 4,1$ & $24,5 \pm 3,5$ & $8,7 \pm 2,4$ \\
\hline 4. & Побутові умови & $8,5 \pm 2,4$ & $10,1 \pm 2,6$ & $38,2 \pm 4,1$ & $28,8 \pm 3,9$ & $14,4 \pm 2,9$ \\
\hline 5. & Матеріальне благополуччя & $9,3 \pm 2,5$ & $10,8 \pm 2,7$ & $31,3 \pm 4,1$ & $33,7 \pm 4,1$ & $14,9 \pm 3,0$ \\
\hline 6. & Відношення у сім'ї & $3,1 \pm 1,5$ & $2,4 \pm 1,3$ & $17,0 \pm 3,3$ & $39,1 \pm 4,0$ & $38,4 \pm 4,2$ \\
\hline 7. & Здоров'я та благополуччя дітей & $5,4 \pm 1,9$ & $7,0 \pm 2,2$ & $27,3 \pm 3,9$ & $39,1 \pm 4,0$ & $21,2 \pm 3,6$ \\
\hline 8. & Харчування & $3,8 \pm 1,6$ & $7,8 \pm 2,3$ & $43,8 \pm 4,3$ & $33,7 \pm 4,1$ & $10,9 \pm 2,6$ \\
\hline 9. & Дозвілля, відпочинок, розваги & $4,6 \pm 1,8$ & $20,3 \pm 3,5$ & $35,8 \pm 4,2$ & $28,2 \pm 3,9$ & $11,0 \pm 2,7$ \\
\hline 10. & Медичне обслуговування & $3,1 \pm 1,5$ & $17,8 \pm 3,3$ & $42,1 \pm 4,3$ & $27,6 \pm 3,8$ & $9,4 \pm 2,5$ \\
\hline 11. & Соціальний та правовий захист & $25,0 \pm 3,8$ & $25,7 \pm 3,8$ & $38,2 \pm 4,1$ & $9,4 \pm 2,5$ & $1,6 \pm 0,9$ \\
\hline
\end{tabular}

Таким чином, результати проведених досліджень дозволили визначити найвагоміші проблеми щодо умов життя військовослужбовців ВМС ЗС України. Перш за все - незабезпеченість житлом, низький рівень матеріального благополуччя та недостатній рівень соціального і правового захисту. Майже половина військовослужбовців в деякій мірі задоволені роботою, медичним обслуговуванням, проведенням дозвілля, відпочинку та харчуванням, мають певну надію на перспективу свого службового зростання, задовільні відношення у сім'ї (аналіз сімейного стану респондентів свідчить 
про досить значну частку одружених військовослужбовців $(89,1 \pm 2,6 \%)$ та незначну неодружених і розведених (вдівців) відповідно - 2,3 $\pm 1,3 \%$ та $8,6 \pm 2,4 \%$ ). За результатами проведеного опитування, $\quad 78,1 \pm 3,6 \%$ військовослужбовців вважають себе оптимістами, $49,7 \pm 4,4 \%$ не схильні до довготривалого переживання негативних емоцій.

Отже, незважаючи на досить високу обізнаність військовослужбовців ВMC $3 \mathrm{C}$ України щодо вимог здорового способу життя,

\section{Висновки}

1. Встановлено, що для військовослужбовців ВМС 3С України типовими чинниками, що знижують рівень здорового способу життя, $\epsilon$ порушення режиму харчування, режиму праці та відпочинку, високий рівень шкідливих звичок та недостатній рівень фізичної активності.

2. Незважаючи на досить високу обізнаність військовослужбовців ВМС $3 \mathrm{C}$ України щодо вимог здорового способу життя, виконання даних рекомендацій залишається низьким, що піднімає проблему формування здорового способу життя у 3С України до найбільш актуальних.

3. Виявлено невідповідність між високим рівнем поінформованості військовослужбовців ВМС ЗС України щодо здорового способу життя i практичним виконанням цих заходів $(98,1 \pm 1,1 \%$

\section{Література}

1. ро схвалення Концепції Загальнодержавної програми “Здоров'я 2020: український вимір”: Розпорядження Кабінету Міністрів України від 31.10.2011 p. №1164-p. https://zakon.rada.gov.ua/ laws/show/1164-2011-p\#Text.

2. Загальна теорія здоров'я та здоров'язбереження: колективна монографія / заг. ред. проф. Ю. Д. Бойчук. Харків: Вид. Рожко С. Г., 2017. 488

http://hnpu.edu.ua/sites/default/files/files/Kaf zdor ta k orr os/Zagalna teorija zdorovia i zdorviazberegennja.pdf

3. Про затвердження Воєнно-медичної доктрини України : Постанова Кабінету Міністрів України від 31.10.2018 р. № 910. https://zakon.rada.gov.ua/laws/show/910-2018-п\#Text.

4. Розвиток мотивації до здорового способу життя: Інформаційно-методичний посібник для офіцерів та сержантів / укладачі: Бойко О. В., Литвиненко Е. С., Страшко С. В. - Київ : Програма розвитку $\quad 00 \mathrm{H}, \quad 2009 . \quad 166 \quad$ с. http://enpuir.npu.edu.ua/bitstream/123456789/16846/ 1/Мотив_3СЖ 2009\%20\%281\%29.pdf. виконання даних рекомендацій залишається низьким, що піднімає проблему формування здорового способу життя у ЗС України до найбільш актуальних. Для покращення умов життя військовослужбовців ВМС 3С України потребують вирішення наступні питання: забезпечення службовим та постійним житлом, підвищення рівня грошового забезпечення, підвищення рівня соціального і правого забезпечення військовослужбовців та членів їх сімей.

респондентів вважають, що мають достатньо знань про здоровий спосіб життя, але більшість $(56,0 \pm 4,3 \%)$ ці заходи виконують в неповному обсязі у зв'язку 3 наявністю шкідливих звичок $\quad(46,7 \pm 4,3 \%)$ та матеріальних труднощів (29,8ะ4,0\%).

4. Встановлено, що з метою покращення підтримки здорового способу життя за даними соціологічного опитування впровадження матеріального заохочення для військовослужбовців превалює над використанням адміністративних заходів

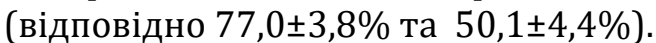

5. Визначено найвагоміші проблеми щодо умов життя військовослужбовців ВМС ЗС України, а саме: незабезпеченість житлом, низький рівень матеріального благополуччя та недостатній рівень соціального і правового захисту.

5. Соціальна медицина і організація охорони здоров'я / за ред. В. Ф. Москаленко. Київ : Книга-ПЛЮС, 2010.328 c.

6. Мороз Г. З., Бібік Т. А., Ткачук І. М. Оцінка медико-соціальних аспектів виконання вимог здорового способу життя військовослужбовцями Київського гарнізону. Проблеми військової охорони здоров'я. Зб. наук. пр. УВМА. К., 2009. Вип. 25. С. 90-98.

7. Grossmeier J. The Art of Health Promotion: linking research to practice. American journal of health promotion : $\begin{array}{llll}\text { AJHP. } & 2018 . & 32(8) . & \text { P. }\end{array}$ https://doi.org/10.1177/0890117118804149

8. Ткачук І. М., Партасюк Н. Ю. Медико-соціальні аспекти виконання вимог здорового способу життя та частота виявлення тривожних та депресивних розладів у військовослужбовців 3 артеріальною гіпертензією. Проблеми військової охорони здоров'я. 2010. Вип. 27. С. 160-169. http://nbuv.gov.ua/UJRN/prvozd 2010_27 20

9. Ehteshami-Afshar S., Momenan A., Hajshekholeslami F., Azizi F., Hadaegh F. The impact of smoking status on 9.3 years incidence of cardiovascular and all-cause mortality among Iranian men. Annals of human 
biology. (2014). 41(3). P. 249-254. https://doi.org/10.3109/03014460.2013.853834

10. Amiri P., Mohammadzadeh-Naziri K., Abbasi B., Cheraghi L., Jalali-Farahani S., Momenan A. A., Amouzegar A., Hadaegh F., Azizi F. Smoking habits and incidence of cardiovascular diseases in men and women: findings of a 12 year follow up among an urban Eastern-Mediterranean population. BMC public health. 2019. 19(1). P. 1042. https://doi.org/10.1186/s12889-019-7390-0

11. Centers for Disease Control and Prevention (US), National Center for Chronic Disease Prevention and Health Promotion (US), \& Office on Smoking and Health (US). (2010). How Tobacco Smoke Causes Disease: The Biology and Behavioral Basis for Smoking-Attributable Disease: A Report of the Surgeon General. Centers for Disease Control and Prevention (US). https://www.ncbinlm.nih.gov/ books/NBK53012/

12. Зубченко С. О. Тютюнокуріння: вплив на здоров'я молоді. Acta Medica Leopoliensia. 2011. XV (1). C. $112-120$.

13. National Center for Chronic Disease Prevention and Health Promotion (US) Office on Smoking and Health. The Health Consequences of Smoking-50 Years of

\section{References}

1. On approval of the Concept of the National Program "Health 2020: Ukrainian Dimension" (2011). Order of the Cabinet of Ministers of Ukraine dated 31.10.2011 №1164r. https://zakon.rada.gov.ua/laws/show/1164-2011p\#Text

2. General Theory of Health and Healthcare: a collective monograph. (2017). According to the general editing by prof. Boychuk, Yu. D. Kharkiv: Rozhko SG, 488. http://hnpu.edu.ua/sites/default/files/files/

Kaf zdor ta korr os/Zagalna teorija zdorovia i zdorviazb eregennja.pdf

3. On approval of the Military Medical Doctrine of Ukraine (2018). Resolution of the Cabinet of Ministers of Ukraine dated 31.10.2018 № 910. https://zakon.rada.gov.ua/laws/show/910-2018-p\#Text

4. Boyko, O.V., Litvinenko, E.S., Strashko, S.V. (2009). Development of motivation for a healthy lifestyle: Information and methodical manual for officers and sergeants. Kyiv: UN Development Program, 166. http://enpuir.npu.edu.ua/bitstream/123456789/16846/ 1/Мотив ЗСЖ 2009\%20\%281\%29.pdf

5. Social medicine and health care organization (2010). Ed. by prof. Moskalenko V.F. Kyiv: Book-PLUS, 328.

6. Moroz, G.Z., Bibik, T.A., Tkachuk, I.M. (2009). Evaluation of medical and social aspects of compliance with the requirements of a healthy lifestyle by servicemen of the Kiev garrison. Problems of military health care: Collection of scientific works of the Ukrainian military medical academy, (25), 90-98.

7. Grossmeier J. (2018). The Art of Health Promotion: linking research to practice. American journal of health promotion : AJHP, 32(8), 1814. https://doi.org/ $10.1177 / 0890117118804149$

8. Tkachuk, I.M., Partasyuk, N. Yu. (2010). Medical and social aspects of meeting the requirements of a healthy lifestyle and the frequency of anxiety and depressive disorders in servicemen with hypertension. Problems of
Progress: A Report of the Surgeon General. Centers for Disease Control and Prevention (US). 2014. 1081 p. PMID: 24455788.

14. Мороз Г. З. Ткачук І. М., Єпішев Ю. П., Міхріна М. I., Кравець А. В., Захарчук Л. М. Тютюнокуріння військовослужбовців: сучасний стан проблеми та готовність до змін нездорової поведінки. Військова медицина України. 2018. Т. 18, № 1. С. 71-76. http://nbuv.gov.ua/UJRN/vmuk_2018_18_1_13

15. Гуліч М. П. Раціональне харчування та здоровий спосіб життя-основні чинники збереження здоров'я населення. Проблемы старения и долголетия. 2011. 20(2). C. 128-132. http://geront.kiev.ua/ library/psid/2011-2.pdf\#page=20

16. Москаленко В. Ф., Грузєва Т. С., Галієнко Л. І. Особливості харчування населення України та їх вплив на здоров'я. Наук. вісн. Нац. мед. ун-ту імені 0.0. Богомольця. Київ : НМУ, 2009. № 3. С. 64-73.

17. Кундієв Ю. І., Чернюк В. І., Шевцова В. М. Напруженість праці як фактор професійного стресу та ризику здоров'ю. Український журнал 3 проблем медицини праці. 2005 . № 3-4. С. 90-98. http://oplib.org.ua/2720/1/05-3 15--.pdf

military health care: Collection of scientific works of the Ukrainian military medical academy, (27), 160-169. http://nbuv.gov.ua/UJRN/prvozd 2010 27 20

9. Ehteshami-Afshar, S., Momenan, A., Hajshekholeslami, F., Azizi, F., \& Hadaegh, F. (2014). The impact of smoking status on 9.3 years incidence of cardiovascular and all-cause mortality among Iranian men. Annals of human biology, 41 (3), 249-254. https://doi.org/10.3109/03014460.2013.853834

10. Amiri, P., Mohammadzadeh-Naziri, K., Abbasi, B., Cheraghi, L., Jalali-Farahani, S., Momenan, AA, Amouzegar, A., Hadaegh, F., \& Azizi, F. (2019). Smoking habits and incidence of cardiovascular diseases in men and women: findings of a 12 year follow up among an urban EasternMediterranean population. BMC public health, 19 (1), 1042. https://doi.org/10.1186/s12889-019-7390-0

11. Centers for Disease Control and Prevention (US), National Center for Chronic Disease Prevention and Health Promotion (US), \& Office on Smoking and Health (US). (2010). How Tobacco Smoke Causes Disease: The Biology and Behavioral Basis for Smoking-Attributable Disease: A Report of the Surgeon General. Centers for Disease Control and Prevention (US). Available from: https://www.ncbi.nlm.nih.gov/books/NBK53012/

12. Zubchenko, S.O. (2011). Smoking: the impact on youth health. Acta Medica Leopoliensia, XV (1), 112-120.

13. National Center for Chronic Disease Prevention and Health Promotion (US) Office on Smoking and Health. (2014). The Health Consequences of Smoking - 50 Years of Progress: A Report of the Surgeon General. Centers for Disease Control and Prevention (US). https://www.ncbi.nlm.nih.gov/books/NBK179276/pdf/B ookshelf NBK179276.pdf

14. Moroz, G.Z., Tkachuk, I.M., Epishev, Y.P., Mikhrina, M.I., Kravets, A.V., Zakharchuk, L.M. (2018). Smoking of servicemen: the current state of the problem and readiness for changes in unhealthy behavior. Military medicine of 
Ukraine, 18 (1), 71-76. $\quad$ http://nbuv.gov.ua/ UJRN/vmuk 201818113

15. Gulich, M.P. (2011). Rational nutrition and a healthy lifestyle are the main factors in maintaining the health of the population. Aging and longevity problems. 20 (2). C. 128132. $\quad$ http://geront.kiev.ua/library/psid/2011-2.pdf\# page $=20$
16. Moskalenko, V.F., Gruzeva, T.S., Galienko, L.I. (2009). Features of nutrition of the population of Ukraine and their impact on health. Scientific bulletin of $O$ Bohomolets National Medical University. 3, 64-73.

17. Kundiev, Y.I., Chernyuk, V.I., Shevtsova, V.M. (2005). Labor intensity as a factor of occupational stress and health risk. Ukrainian Journal of occupational health, 3-4, 90-98. http://oplib.org.ua/2720/1/05-3 15--.pdf

\title{
КОМПЛЕКСНАЯ ОЦЕНКА МЕДИКО-СОЦИАЛЬНЫХ ДЕТЕРМИНАНТ ЗДОРОВОГО ОБРАЗА ЖИЗНИ У ВОЕННОСЛУЖАЩИХ ВОЕННО-МОРСКИХ СИЛ ВООРУЖЕННЫХ СИЛ УКРАИНЫ
}

\author{
И.к. Середа ${ }^{1}$ Ж.М. Олещенко²
}

\author{
1 Украинская военно-медицинская академия, г. Киев, Украина. \\ ${ }^{2}$ Командование Морской пехоты Военно-Морских Сил Вооруженных Сил Украины., Г. Николаев, Украина
}

\begin{abstract}
Цель работы - комплексная оценка медико-социальных детерминант здорового образа жизни у военнослужащих ВМС ВС Украины.

Материалы и методы. Медико-социальные аспекты выполнения требований здорового образа жизни у военнослужащих ВМС ВС Украины были проанализированы по результатам социологического опроса $c$ применением специально разработанной анкеты. Анкета включала 43 вопроса, которые были сгруппированы в информационные блоки. Методом случайной выборки был проведен анкетный опрос 128 военнослужсащих ВМС ВС Украины, которые проходили углубленное медицинское обследование в 2019 году. В исследуемую группу вошли лица мужского пола, средний возраст - 38,5 \pm 0,44 г., с выслугой лет в ВС Украины - 19,68 \pm 0,43 г. Для решения поставленных задач применялись следующие методы: библиографический, медико-социологический, медикостатистический, системный подход.
\end{abstract}

Результаты. В статье рассмотрены медико-социальные аспекты выполнения требований здорового образа жизни у военнослужащих ВМС ВС Украины по результатам социологического опроса с применением специально разработанной анкеты. Анкета включала информационные блоки: общие сведения, осведомленность о здоровом образе жизни, распространенность и причины вредных привычек, анализ образа жизни (особенностей питания, физической активности, режима труда и отдыха), самооценка состояния здоровья и таблицу по определению удовлетворенности различными сторонами жизни за следующим критериям: условия труда и перспективы служебного роста, обеспеченность жильем и бытовые условия, семейное и материальное благополучие, досуг и медицинское обслуживание, социальную и правовую защиту и тому подобное.

Выводы. Несмотря на достаточно высокую осведомленность военнослужащих ВМС ВС Украины относительно требований здорового образа жизни, выполнение рекомендаций по выполнению требований здорового образа жизни остается низким. Выявлено несоответствие между высоким уровнем осведомленности военнослужащих ВМС ВС Украины по здоровому образу жизни и практическим выполнением этих мероприятий (98,1 \pm 1,1\% респондентов считают, что имеют достаточно знаний о здоровом образе жизни, но большинство (56,0 \pm 4,3 \%) эти меры выполняют в неполном объеме в связи с наличием вредных привычек (46,7 \pm 4,3\%) и материальных трудностей (29,8 4 4,0\%). Кроме того, для военнослужащих ВМС ВС Украины типичным является нарушение режима питания, режима труда и отдыха, высокий уровень вредных привычек и недостаточный уровень физической активности. Установлено, что с целью улучшения поддержки здорового образа жизни по данным социологического опроса внедрения материального поощрения для военнослужащих превалирует над использованием административных мер (соответственно 77,0 \pm 3,8\% и 50,1 \pm 4,4\%). Определены наиболее значимые проблемы по условиям жизни военнослужащих ВМС ВС Украины, а именно: необеспеченность жильем, низкий уровень материального благополучия и недостаточный уровень социальной и правовой защиты.

Ключевые слова: военнослужащие Военно-Морских Сил ВС Украины, здоровый образ жизни, факторы риска.

\section{COMPREHENSIVE ASSESSMENT OF MEDICAL AND SOCIAL DETERMINANTS OF HEALTHY LIFESTYLE AMONG SERVICEMEN OF THE NAVAL FORCES OF THE ARMED FORCES OF UKRAINE}

\author{
I.K. Sereda' ${ }^{1}$ Zh.M. Oleshchenko² \\ 1 Ukrainian Military Medical Academy, Kyiv, Ukraine \\ ${ }^{2}$ Marine Command of the Naval Forces of the Armed Forces of Ukraine, Mykolaiv, Ukraine
}

The purpose is to comprehensively assess the medical and social determinants of a healthy lifestyle in the servicemen of the Navy of the Armed Forces of Ukraine to identify the most important risks and develop on this basis focused measures to reduce them.

Materials and methods. Medical and social aspects of fulfilling the requirements of a healthy lifestyle in servicemen of the Navy of the Armed Forces of Ukraine based on the results of a sociological survey using a specially 
designed questionnaire have been analyzed. The questionnaire included 43 requests, which were summarized in some information blocks. A questionnaire was used to conduct a questionnaire survey of 128 servicemen of the Navy servicemen who underwent an in-depth medical examination in 2019. The study group included males, average age $38.5 \pm 0.44$, with $19.68 \pm 0.43$ years of service in the Armed Forces of Ukraine. Methods - bibliographic, medical and sociological, medical-statistical, system analysis.

Results. The article considers the medical and social aspects of meeting the requirements of a healthy lifestyle among servicemen of the Navy of the Armed Forces of Ukraine based on the results of a poll using a specially designed questionnaire. The questionnaire included information blocks: general information, awareness of a healthy lifestyle, prevalence and causes of bad habits, analysis of lifestyle (diet, physical activity, work and rest), self-assessment of health and a table for determining satisfaction with different aspects of life by the following criteria: working conditions and career prospects, housing and living conditions, family and material well-being, leisure and medical care, social and legal protection, etc.

Conclusions. It was established that typical factors that reduce the level of a healthy lifestyle among Navy servicemen of the Armed Forces of Ukraine are violations of diet, work and rest, high levels of bad habits and insufficient level of physical activity. Despite the relatively high awareness of Navy servicemen of the Armed Forces of Ukraine on the requirements of a healthy lifestyle, the implementation of these recommendations remains low, which raises the issue of forming a healthy lifestyle in the Armed Forces of Ukraine to the most relevant. There is a discrepancy between the high level of awareness of servicemen of the Navy of the Armed Forces of Ukraine about a healthy lifestyle and the practical implementation of these measures $(98.1 \pm 1.1 \%$ of respondents believe that they have enough knowledge about a healthy lifestyle, but most (56.0 $\pm 4.3 \%)$ these measures are performed incompletely due to the presence of bad habits (46.7 $\pm 4.3 \%$ ) and financial difficulties (29.8 $\pm 4.0 \%)$. It is established that in order to improve the maintenance of a healthy lifestyle, according to a sociological survey, the introduction of material incentives for servicemen prevails over the use of administrative measures $(77.0 \pm 3.8 \%$ and $50.1 \pm 4.4 \%$, respectively). The most important problems concerning the living conditions of Navy servicemen of the Armed Forces of Ukraine have been identified, namely: lack of housing, low level of material well-being and insufficient level of social and legal protection.

Key words: servicemen of the Naval Forces of the Armed Forces of Ukraine, healthy lifestyle, risk factors.

Конфлікт інтересів: відсутній.

Conflicts of interest: authors have no conflict of interest to declare.

\section{Відомості про авторів:}

Середа I.K. A,B,C,D,E,F - підполковник медичної служби, к.мед.н., доцент, доцент кафедри організації медичного забезпечення збройних сил Української військово-медичної академії, м. Київ.

Олещенко Ж.М. В,С,D - підполковник медичної служби, начальник медичної служби Морської Піхоти Військово-Морських Сил Збройних Сил України, м. Миколаїв.

$A$ - концепція та дизайн дослідження; B - збір даних; $C$ - аналіз та інтерпретація даних;

$D$ - написання статmi; $E$ - редагування статmi; $F$ - остаточне затвердження статті.

\section{Сведения об авторах:}

Середа И.К. - подполковник медицинской службы, к.мед.н., доцент, доцент кафедры организации медицинского обеспечения вооруженных сил Украинской военно-медицинской академии, г. Киев.

Олещенко Ж.Н. - подполковник медицинской службы, начальник медицинской службы Морской Пехоты Военно-Морских Сил Вооруженных Сил Украины, г. Николаев.

Information about authors:

Sereda I.K. A,B,C,D,E,F - LtC MS, PhD, Associate Professor, associate professor of the Department of Armed Forces Medical Support of the Ukrainian Military Medical Academy, Kyiv, Ukraine. E-mail irensereda@ukr.net, https://orcid.org/0000-0003-4013-6941.

Oleshchenko Zh.M. B, C, D - LtC MS, Chief of the Medical Service of Marine Command of the Naval Forces of the Armed Forces of Ukraine, Mykolaiv, Ukraine.

$A$ - research concept and design; $B$ - collection and/or assembly of data; $C$-data analysis and interpretation;

$D$-writing the article; $E$-critical revision of the article; $F$-final approval of the article.

Адреса для листування: вул. Московська, 45/1, буд. 33, м. Київ 01015 